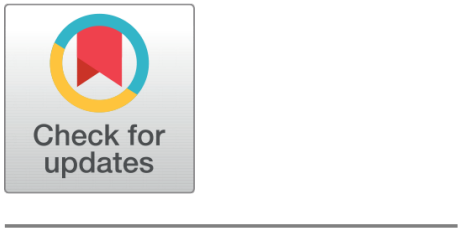

OPEN ACCESS

Received: 22.07.2020

Accepted: 06.04.2021

Published: 17.04.2021

Citation: Castillo-Aguilar MA, Roa-Angulo V (2021) Birdwatching

Tourism and Environmental Education as Strategies for the Conservation of Wetlands in the City of Bogotá, Colombia. Indian Journal of Science and Technology 14(13): 1036-1043. https://doi.org/ 10.17485/IJST/V14i13.1163

* Corresponding author.

Tel: 0057-1-316-8741625

castillomonica@unbosque.edu.co

Funding: None

Competing Interests: None

Copyright: (c) 2021 Castillo-Aguilar \& Roa-Angulo. This is an open access article distributed under the terms of the Creative Commons Attribution License, which permits unrestricted use, distribution, and reproduction in any medium, provided the original author and source are credited.

Published By Indian Society for Education and Environment (iSee)

ISSN

Print: 0974-6846

Electronic: 0974-5645

\section{Birdwatching Tourism and Environmental Education as Strategies for the Conservation of Wetlands in the City of Bogotá, Colombia}

\author{
Monica Andrea Castillo-Aguilar ${ }^{1 *}$, Virginia Roa-Angulo ${ }^{1}$ \\ 1 Biology Research Group-GRIB, Faculty of Sciences, Department of Biology, El Bosque \\ University, Avenue 9 \# 131a- 02, 110121, Bogotá, Colombia. Tel.: 0057-1-316-8741625
}

\begin{abstract}
Objectives: To present a theoretic proposal involving avitourism and environmental education that contributes to conservation and sustainability of the matrix between urban and natural areas focused in Wetland in Bogotá, Colombia. Methods/statistical analysis: Actor's analysis was carried out using semistructured interviews and surveys. On-site visits were used to evaluate the current conditions for performing birdwatching activities at Tibabuyes-Juan Amarillo, Jaboque and Córdoba wetlands in the city of Bogotá. Findings: This work considers the connection among birdwatching tourism in wetlands, environmental education and education institutions. Strategies for the creation of environmental awareness in children and wetland sustainability are proposed, including the creation of interpretative pathways with guided tours, workshops, environmental activities and the possibility of volunteer work. Applications: Environmental and financial benefits could be obtained, with proper planning and management.
\end{abstract}

Keywords: Birdwatching Tourism; Conservation; Environmental Education; Sustainable Management; Wetlands

\section{Introduction}

The concept of wetland has several edges. The definition of the Ramsar Convention ${ }^{(1)}$ on Wetlands is one of the most used, favoring the conservation and proper management of these natural environments and highlighting the main function of water as a controlling factor of the ecosystem structure. Wetlands are ecosystems characterized by their great natural value. In the city of Bogotá, wetlands' high plant diversity, composed of trees and shrub species of terrestrial, aquatic and semi-aquatic habits, are home of more than 160 of native and migratory birds.

These are highly vulnerable environments in Colombia. Nature-society interaction has modified wetlands' dynamics, giving rise to changes in the coverage of the afferent basins and drainage. Activities such as wetland fragmentation have transformed water quality and altered the nutrient dynamics and seasonality of the system ${ }^{(2)}$. These ecosystems are of vital importance, they are home to a high number of species. 
Some endangered or threatened of extinction as a consequence of stratification and loss of habitat ${ }^{(3-5)}$, due to contamination and loss of water quality ${ }^{(6,7)}$, or the expansion of the urban border ${ }^{(8)}$.

However, wetlands provide the necessary conditions for the establishment of aquatic birds, where species richness and abundance depends on the hydrological regime, the size and heterogeneity of the site/area, and the structure of the vegetation. The high diversity of Neotropical bird species, together with diverse migratory bird's species, and latitudinal migrants ${ }^{\left({ }^{9}\right.}$, favors the practice of birdwatching.

Birdwatching tourism is defined as the set of for-profit activities consisting of facilitating all kinds of people to observe birds in natural areas as a means of recreation, research and scientific development ${ }^{(10)}$. It is currently considered one of the most developed activities in tourism, with a growing market volume. Colombia stands out as a world birding destination due to its high probability of effective encounter and the great diversity of birds in reduced areas. Thus, the interest in birdwatching has become a tool for the conservation not only of birds but also of the ecosystems and environments in which they live, strengthening local development.

Environmental education seeks the care of the environment and the possibility of acquiring values, attitudes and skills necessary to protect and improve human life on the planet. Environmental education research has shown that changing human relationships with the environment requires an increasing knowledge about the environment that leads to changing human attitudes towards conservation ${ }^{(11)}$. Environmental education has gained a importance over time: social, environmental and educational ${ }^{(12)}$ which, through different schools of thought, ideological and ethical practices, have allowed the construction of educational tools with vocation and integration of human development and reconciliation with the environment.

Mitigating impacts and contributing to biodiversity conservation is a great challenge in large cities, where the accelerated increase in urban settlement has diminished natural areas. The effects of large cities on the areas in which they develop are profound, substituting natural ecosystems and altering the original flora and fauna ${ }^{(13)}$. Consideration of strategies that promote local development by linking communities that integrate natural, social and human components ${ }^{(14)}$, can be a tool that favors the conservation of birds and natural environments, generating socio-economic and participatory benefits.

\section{Methods}

Contact was made with the entities in charge of wetland management, "Empresa de Acueducto y Alcantarillado de Bogotá" (EAAB) and "Secretaría Distrital de Ambiente" (SDA) to have access to three wetlands of the Bogotá city: Tibabuyes-Juan Amarillo, Jaboque and Córdoba. The author's made tours accompanied by officials or groups of bird's watchers. During the tours, each bird observed was recorded. The diversity of birds was estimated to explore the probability of encounters with the avifauna and the diversity of birds with a sampling effort of $56 \mathrm{man} /$ hours.

The authors defined six groups of people for the development of the stakeholder matrix. Wetland visitor: those who attend the wetland with an interest in knowing the place, wetland neighbors: people who live nearby; birds watchers: interested in spotting wetland birds; EAAB workers: workers in charge of maintaining the wetland; Overseers of Popular Action - H. de Córdoba: defender of environmental actions of the Wetland Córdoba, to know the perspective on wetlands, conservation, environmental education and bird tourism, through using nine semi-structured interviews and seven surveys for wetland. With the interviews and surveys collected information regarding people's perception of the environmental education, activities and birdwatching. The authors developed a reflective proposal of birdwatching tourism and environmental education as strategies for the conservation of the Bogotá wetlands.

\section{Results}

\section{Stakeholder matrix}

The stakeholder matrix (Table 1) allowed the identification of interests and highlighted the problems from the point of view of each actor according to their relationship with wetlands. 
Table 1. Stakeholder matrix in the three wetlands,Tibabuyes-Juan Amarillo, Jaboque and Córdoba

\begin{tabular}{|c|c|c|c|}
\hline Groups & Interest & Perceived problems & Agreements and resources \\
\hline Visitors & $\begin{array}{l}\text { Guided tours } \\
\text { Safe and quiet routes } \\
\text { Connection with nature }\end{array}$ & $\begin{array}{l}\text { Insecurity when visiting wetlands } \\
\text { Lack of accompaniment } \\
\text { Lack of information on time tables, work- } \\
\text { shops and guided tours } \\
\text { Inadequate roads }\end{array}$ & $\begin{array}{l}\text { Reinforcement of security in } \\
\text { the area } \\
\text { Presence of a continuous } \\
\text { environmental facilitator }\end{array}$ \\
\hline Birds watchers & $\begin{array}{l}\text { Develop routes defined for visitors } \\
\text { according to avifauna experience } \\
\text { Develop a proposal that prevents the } \\
\text { deterioration of wetlands }\end{array}$ & $\begin{array}{l}\text { Lack of bridges and crossings that facili- } \\
\text { tate the passage between aquatic areas } \\
\text { Good signaling of wetland interactions } \\
\text { and biological function }\end{array}$ & $\begin{array}{l}\text { Appropriate proposals with } \\
\text { little landscape intervention } \\
\text { Design of informative panels }\end{array}$ \\
\hline Wetland neighbors & $\begin{array}{l}\text { Signals information to learn more } \\
\text { about the ecosystem and species } \\
\text { Safety and good lawn management }\end{array}$ & $\begin{array}{l}\text { Ignorance of the functioning of wetlands } \\
\text { as ecosystems } \\
\text { Insecurity and vandalism } \\
\text { Vegetation management }\end{array}$ & $\begin{array}{l}\text { Workshops design of ecosys- } \\
\text { tem unction } \\
\text { Reinforcement of security in } \\
\text { the area }\end{array}$ \\
\hline EAAB workers & $\begin{array}{l}\text { Good water quality } \\
\text { Improve erroneous water connec- } \\
\text { tions }\end{array}$ & $\begin{array}{l}\text { Erroneous connections between canals } \\
\text { and wetlands } \\
\text { Clogging and bad smells } \\
\text { Excess organic matter }\end{array}$ & $\begin{array}{l}\text { Analysis of water manage- } \\
\text { ment programs? and educa- } \\
\text { tional campaigns }\end{array}$ \\
\hline Guard of the zones & $\begin{array}{l}\text { Ensuring security in wetlands } \\
\text { Proper handling of feral dogs }\end{array}$ & $\begin{array}{l}\text { Insecurity and support from the National } \\
\text { Police } \\
\text { security with enclosures } \\
\text { Presence of feral dogs }\end{array}$ & $\begin{array}{l}\text { Reinforcement of security in } \\
\text { the area }\end{array}$ \\
\hline $\begin{array}{l}\text { Overseers of Popu- } \\
\text { lar Action - Wet- } \\
\text { land. Córdoba }\end{array}$ & $\begin{array}{l}\text { Presence of environmental skilled } \\
\text { facilitators } \\
\text { Neighboring groups of people inter- } \\
\text { ested in birding activities }\end{array}$ & $\begin{array}{l}\text { Difficulty in communication channels } \\
\text { with EAAB } \\
\text { Neighbors and visitors who are not very } \\
\text { sensitive to the wetland }\end{array}$ & $\begin{array}{l}\text { Presence of a continuous } \\
\text { environmental facilitator } \\
\text { Raising awareness among } \\
\text { visitors }\end{array}$ \\
\hline
\end{tabular}

Source: The authors

Tibabuyes-Juan Amarillo, Jaboque and Córdoba wetlands have corridors delimiting the area of the water, on which paths have been designed in a rustic manner, being the areas used for birdwatching visits. The Córdoba wetland has an elevated path of $1.2 \mathrm{~km}$ that facilitates and systematizes almost all visits. The Tibabuyes-Juan Amarillo and Córdoba wetlands have administrative headquarters for contact and organization of visits. All the wetlands have signs for birdwatching and information about the District Ecological Parks and viewpoint zones for birdwatching.

\section{Bird diversity and abundance}

From the visits carried out, we obtained a list of birds observed (Table 2). Córdoba wetland, despite being the smallest (40.4 ha) is present the greatest bird diversity, with $41 s p p$. compared with 25 and 26 in the other wetlands. The higher spp. diversity is probably explained to the role of engaged community of neighbors. For 17 years the neighbors have actively participated in the protection, management and conservation. Through a legal action (Popular Action00-254 of 2000), they have been able to be actively involvement in the management and planning of environmental activities carried out in this wetland.

Table 2. List of birds observed in the wetlandsTibabuyes-Juan Amarillo, Jaboque and Córdoba

\begin{tabular}{|c|c|c|c|c|}
\hline \multirow{2}{*}{ Scientific name } & \multirow{2}{*}{ Common name } & \multicolumn{3}{|l|}{ Wetlands } \\
\hline & & Juan Amarillo (222 ha) & Jaboque (140 ha) & Córdoba (40.4 ha) \\
\hline Anas discors & Canadian duck & $\checkmark$ & $\checkmark$ & $\checkmark$ \\
\hline Ardea alba & Grey heron & $\checkmark$ & $\checkmark$ & $\checkmark$ \\
\hline Bubulcus ibis & Cattle heron & $\boldsymbol{V}$ & & \\
\hline Butorides striata & Green heron & & $\boldsymbol{\nu}$ & $\checkmark$ \\
\hline Calidris melanotos & Pectoral sandpiper & & & $\boldsymbol{\nu}$ \\
\hline Megascops choliba & Tropical Screech-owl & & & $\boldsymbol{\sim}$ \\
\hline Coccyzus americanus & Yellow-billed cuckoo & & $\boldsymbol{\nu}$ & $\checkmark$ \\
\hline Colibri coruscans & Sparkilng violet-ear & $\checkmark$ & $\checkmark$ & $\boldsymbol{V}$ \\
\hline Contopus cinereus & Southern tropical pewee & & & $\boldsymbol{V}$ \\
\hline
\end{tabular}




\begin{tabular}{|c|c|c|c|c|}
\hline \multicolumn{5}{|c|}{ Table 2 continued } \\
\hline Coragyps atratus & American black vulture & $v$ & $\boldsymbol{\nu}$ & \\
\hline Crotophaga major & Greater ani & & & $\boldsymbol{\nu}$ \\
\hline Chrysomus icterocephalus & Yellow hooded blackbird & $\checkmark$ & $\boldsymbol{v}$ & $\boldsymbol{\nu}$ \\
\hline Diglossa humeralis & Black flowerpiercer & $\boldsymbol{\nu}$ & $\boldsymbol{\nu}$ & $\boldsymbol{\nu}$ \\
\hline Elaenia frantzii & Mountain elaenia & & & $\boldsymbol{\nu}$ \\
\hline Elanus leucurus & White-tailed kite & $\boldsymbol{\nu}$ & $\boldsymbol{\nu}$ & \\
\hline Forpus conspicillatus & Spectacled parrotlet & & & $\boldsymbol{\nu}$ \\
\hline Fulica americana & American coot & $\boldsymbol{\nu}$ & $\boldsymbol{\nu}$ & $\boldsymbol{v}$ \\
\hline Gallinula galeata & Commun gallinule & $\boldsymbol{\nu}$ & $\boldsymbol{\nu}$ & $\boldsymbol{\nu}$ \\
\hline Gallinula melanops & Spot-flanked gallinule & $\boldsymbol{\nu}$ & & \\
\hline Icterus chrysater & Yellow-backed oriole & & $\boldsymbol{\nu}$ & $\boldsymbol{\nu}$ \\
\hline Icterus nigrogularis & Yellow Oriole & & $\boldsymbol{v}$ & $\boldsymbol{v}$ \\
\hline Lesbia nuna & Green-tailed trainbearer & & & $\boldsymbol{\nu}$ \\
\hline Molothrus bonariensis & Shiny cowbird & $\boldsymbol{\nu}$ & $\boldsymbol{\nu}$ & $\boldsymbol{v}$ \\
\hline Nycticorax nycticorax & Black.crowned night.heron & $\boldsymbol{\nu}$ & $\boldsymbol{\nu}$ & $\boldsymbol{\nu}$ \\
\hline Oxyura jamaicensis & Ruddy duck & $\boldsymbol{\nu}$ & $\boldsymbol{v}$ & $\boldsymbol{v}$ \\
\hline Ochthoeca fumicolor & Brown-backed chat-tyrant & & & $\boldsymbol{\nu}$ \\
\hline Phalacrocorax brasilianus & Neotropical cormorant & $\boldsymbol{\nu}$ & $\boldsymbol{\nu}$ & $\boldsymbol{\nu}$ \\
\hline Pheuticus aureoventris & Bababuy & & & $\boldsymbol{v}$ \\
\hline Phimosus infuscatus & Bare-faced ibis & & $\boldsymbol{\nu}$ & $\boldsymbol{v}$ \\
\hline Piranga rubra & Summer Tanager & & & 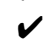 \\
\hline Pitangus sulphuratus & Great kiskadee & $\boldsymbol{\nu}$ & $\boldsymbol{\nu}$ & $\boldsymbol{v}$ \\
\hline Podilymbus podiceps & Pied-billed Grebe & $\checkmark$ & & $\boldsymbol{v}$ \\
\hline Rupornis magnirostris & Roadside Hawk & & & $\boldsymbol{\nu}$ \\
\hline Setophaga fusca & Blackburnian Warbler & & $\boldsymbol{v}$ & $\boldsymbol{v}$ \\
\hline Sicalis flaveola & Saffron finch & & $\boldsymbol{v}$ & $\boldsymbol{\nu}$ \\
\hline Spinus spinescens & Andean siskin & $\boldsymbol{v}$ & & \\
\hline Thraupis episcopus & Blue-grey Tanager & $\boldsymbol{v}$ & & $\boldsymbol{\nu}$ \\
\hline Thraupis palmarum & Palm Tanager & 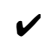 & & $\boldsymbol{v}$ \\
\hline Tringa solitaria & Solitary sandpiper & $\boldsymbol{v}$ & & $\boldsymbol{\nu}$ \\
\hline Turdus fuscater & Great Thrush & $\boldsymbol{v}$ & $\boldsymbol{v}$ & $\boldsymbol{v}$ \\
\hline Tyrannus melancholicus & Tropical kingbird & & $\boldsymbol{v}$ & $\boldsymbol{v}$ \\
\hline Tyrannus savana & Fork-tailed flycatcher & & & $\boldsymbol{v}$ \\
\hline Tyrannus tyrannus & Eastern kingbird & $\boldsymbol{\nu}$ & & $\boldsymbol{v}$ \\
\hline Vanellus chilensis & Southern lapwing & $\boldsymbol{\nu}$ & $\boldsymbol{v}$ & \\
\hline Vireo olivaceus & Red-eyed Vireo & & & $\boldsymbol{v}$ \\
\hline Zenaida auriculata & Eared dove & $\boldsymbol{\nu}$ & $\boldsymbol{\nu}$ & $\boldsymbol{v}$ \\
\hline Zonotrichia capensis & Rufous-collared Sparrow & & $\boldsymbol{v}$ & $\boldsymbol{v}$ \\
\hline & & 25 & 26 & 41 \\
\hline
\end{tabular}

Source: Own preparation

\section{Sustainable Management of birdwatching Tourism in the Wetlands of the city of Bogotá}

The proposal contains three main actions (Table 3), focusing on improving the physical infrastructure, strengthening environmental activities and increasing economic resources.

Table 3. Actions and activities for the project Sustainable Management of birdwatching in the Wetlands in Bogotá city

\begin{tabular}{lll}
\hline Infrastructure and physical aspects & Strengthening of environmental activities & Economic resources \\
\hline - Roads & $\bullet$ Water quality monitoring & $\bullet$ Offer of workshops and environ- \\
- Sighting towers and viewpoints & $\bullet$ Interpretative sighting trails & mental activities \\
- Signals & $\bullet$ Volunteer Programs & $\bullet$ Preliminary analysis of load capacity \\
- Security and enclosure & $\bullet$ Environmental Facilitator Volunteer & \\
- Ecological flows and water mirror cleaning & Programs & $\bullet$ Sale of informative material \\
- Removal of invasive vegetation & $\bullet$ Training of personnel & \\
- Extraction of solid waste and rubble & & \\
\hline
\end{tabular}

Source: The authors 
The proposal considers in its first action the need to improve infrastructure, environmental quality and safety to ensure the tranquility of visitors and the use of environmental services provided by these ecosystems. For the second action, the opportunity was to strengthen environmental activities through monitoring and follow-up of water quality, and the layout of interpretative trails. These trails are considered as educational tools that can be used in natural areas to integrate social groups to conservation processes through environmental education. Hence, these trails allow visitors to come into direct contact with the values of the environment ${ }^{(15)}$.

Birdwatching activities require displacement by those interested. We propose the development of structures that facilitate mobility and the use of areas of high visibility. These structures will have more extensive sightings areas. Therefore we suggest the use of sighting towers, trails and viewpoints in open areas Figure 1 to favor observation at a greater distance. We designed routes based on the experience of bird-observation visitors. They consist of two types of routes with the use of ramps and/or connecting bridges in the critical points to facilitate the passage of the visitors Figure 2 and to be used by people with movement restrictions.
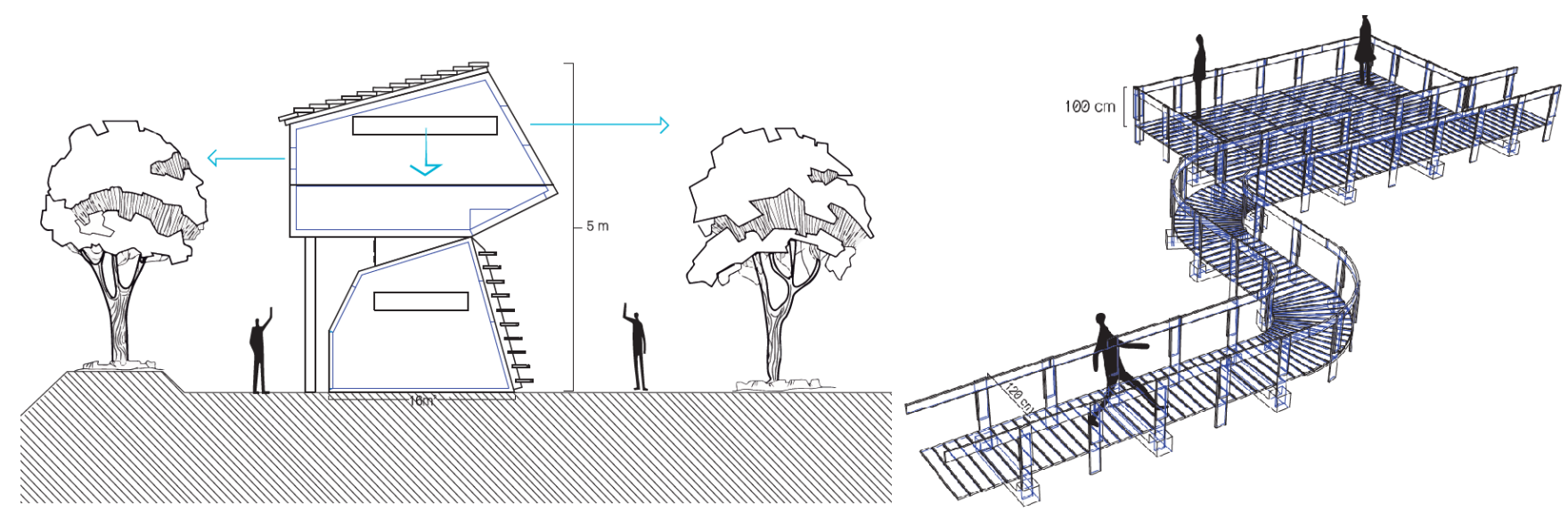

Fig 1. Plans of the proposed sighting towers, trails and viewpoints. Designed in Adobe illustrator CC

- Beginner routes: 2 to $4 \mathrm{~km}$ routes, simple terrain and open areas with easy birdwatching areas, with viewpoints and sighting towers

- Advanced routes: 4 to $10 \mathrm{~km}$ long routes and more difficult roads given by the systemic complexity of the wetland for people who have birdwatching expertise.

For the proper development of these strategies, the presence of environmental facilitators is important. The facilitators should be people trained and committed to the development of activities including those related to social participation and identification of possible socio-environmental impacts. Facilitates should be considered as proactive individuals for the good of the community and the environment. It is important to offer workshops and environmental activities as part of the sustainable development through environmental education. These educational activities contribute to the progressive transformation of human's attitude towards the environment. Workshops are proposed with specific topics such as: Initiation in Bird Observation, Citizen Environmental Culture, Nature and Landscape Photography, Environmental Awareness and Conservation, Sustainable Use of Natural Resources, Migratory Birds and Wetlands. 


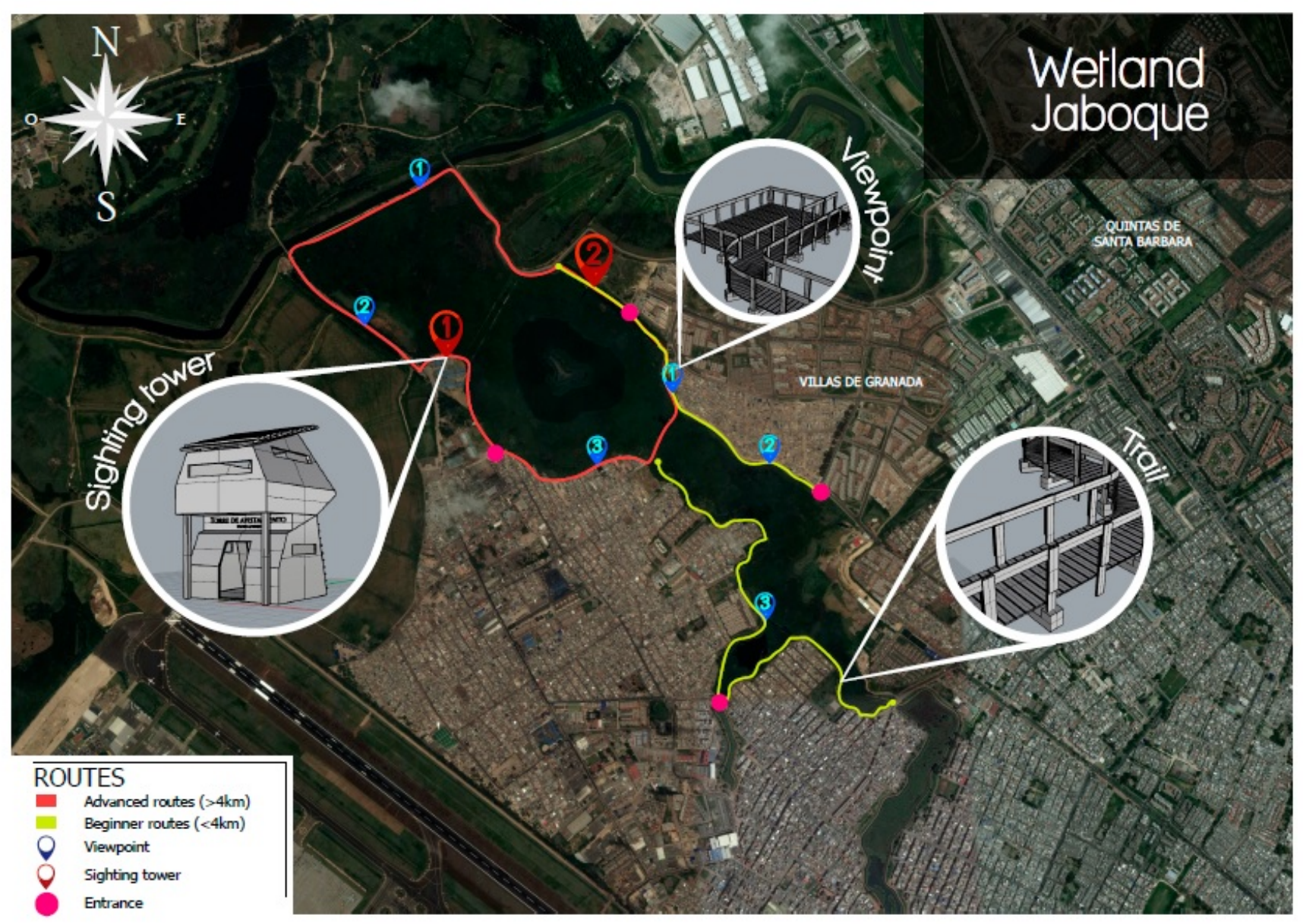

Fig 2. Map of Jaboque wetland with location of trails, viewpoints and sighting towers, 3D representation developed in Rhinoceros 5.0.

Likewise, a volunteer program is proposed through the creation of social movements driven by solidarity that is directed towards the support of problem solving. Volunteers are one of the most active and profound aspects of citizen participation in our contemporary society and are born of the free and disinterested assumption of personal and social responsibility ${ }^{(16)}$. These programs are considered social participation strategies that contribute to the benefit of the community. The third action suggests activities that contribute to the increase of financial resources, which can be allocated for site improvements and/or activities that favor visitors. It also relates and brings visitors closer to wetlands and birdwatching tourism practices.

\section{Discussion}

The wetlands of the city of Bogotá present problems of environmental degradation generated by the dynamics of urban growth associated with changes in land use. Among the problems highlighted by those involved is the lack of accompaniment and lack of information on schedules, workshops and visits that can be made, as well as ignorance about wetlands as transcendental ecosystems in the urban matrix, generating interest and concern from environmental management, by increasing their vulnerability and deterioration.

Birds observed in the wetlands make possible to analyze the level of conservation of these ecosystems, given their role as indicators of environmental quality, due to their sensitivity to noise and environmental pollution ${ }^{(17)}$. They can also indicate some habitat characteristics and their presence or absence helps to understand patterns of environmental impacts ${ }^{(18)}$. Córdoba wetland has a better environmental quality not only because of the number of birds observed, but also because of the absence of invasive vegetation and the presence of an ecological flow that favors the constant flow of water, reducing the concentration of organic matter, activities reached by the protection action decreed. 
Of the 188 species recorded in three Bogotá wetlands, 65 are migratory species (35\% of the total), constituting an important proportion of the avifauna in the city's Wetland District Ecological Parks-PEDH ${ }^{(19)}$. Birdwatching tourism is available throughout the year, offering the possibility of encounter with birds during the different climatic seasons. Socialization of the viability of observing birds with a high percentage of encounters, for those interested and for experts in birdwatching, becomes a tourist attraction that needs to be published through massive communication channels (web pages) and through groups of ornithologists and people interested in birds.

Birdwatching tourism requires displacement on the part of the interested parties, structures are proposed that facilitate the mobility and the advantage of zones of wide visibility. Interpretative trails are an attractive strategy that benefits natural areas by generating economic returns that can be invested in each wetland for management and conservation, promoting environmental value among visitors and neighbors.

Including volunteer programs in the sustainable management plan for birdwatching tourism in the Bogotá wetlands would generate links between entities and citizens, favoring the monitoring and conservation of natural areas. Likewise, linking people motivated to help selflessly creates a positive social and environmental impact. It is proposed to establish contact with educational institutions to generate a participation agreement and fulfill the commitments of the Environmental Education Policy of the National Environmental System -SINA, which includes the environmental dimension in formal education ${ }^{(20)}$, through School Environmental Projects -PRAE.

The PRAE respond to the mandate stipulated by Law 115/1994 ${ }^{(21)}$, which establishes the General Education Law, defining environmental education as a mandatory subject in public and private educational institutions. It seeks to respond to the need to acquire awareness of conservation, protection and improvement of the environment, quality of life, rational use of natural resources and disaster prevention.

As a value aspect of the project, positive scenarios are proposed that could be generated by its development:

- Improvement in the biological conditions of the aquatic system and recovery of the natural conditions of the wetlands: The removal of invasive vegetation, the construction of ecological flows, the removal of solid waste and debris, and water quality monitoring would improve the natural conditions of the wetlands, promoting the natural processes of recovery and natural succession of ecosystems.

- Contribution in the conservation of wetlands and birdlife: The conditions planned for the offer of birdwatching tourism in the three wetlands of Bogotá, would favor the conservation and protection of these ecosystems, if the number of visits is adequately managed.

- Government entities driven to improve the quality of natural ecosystems within cities: It has the advantage of the commitment of institutions to improve the quality of natural resources in the ecosystems within the city trough the financial resources of these entities.

- Increased interest and programmed visits to wetlands for birdwatching tourism purposes: The offer of organized plans, with adequate infrastructure and security, would improve and increase the number of visits of different interest groups.

- Participation of citizens in volunteer programs: Volunteer programs allow for the approach between the social and environmental components of the city. To offer the possibility of training, gaining experience and giving voluntary work to the care of natural ecosystems, is to open a window to new proposals favorable to the natural environments of the city.

- Increase in financial resources for each wetland that would allow a reinvestment for the continuation of the project: The sale of quality ecotourism services, which guarantee safety conditions for tourists and visitors, favor the maintenance in time of the birdwatching offer and the acquisition of economic resources. Likewise, the sale of information material of birdlife in Colombia is within the texts of interest and high rotation.

In order to carry out the proposal, the support of the public companies of the city such as EAAB, responsible for the management and maintenance of the water resource and SDA, in charge of trail management, vegetation and administration of the Wetland District Ecological Parks-PEDH of the city is proposed. With the participation of these institutions and the articulation of a bidding company responsible for the proposed actions and activities, the aim is to improve wetland conditions for the development of environmental education activities. Their participation in the conservation and protection of these ecosystems through birdwatching tourism contribute to the creation of responsible environmental behavior through participatory ties and social responsibility.

\section{Conclusions}

The stakeholder analysis made it possible to highlight the interests and define the problems of the wetlands from the perspective of each actor, favoring the global analysis of this work and orienting the three actions and activities proposed for the Sustainable Management of Birdwatching in the Wetlands of the city of Bogotá project. 
Birdwatching tourism was analyzed as a practice that contributes to the conservation of wetlands, through the analysis of current conditions, the effectiveness of birdwatching and the number of species observed.

The wetlands of the city of Bogotá require rapid intervention to ensure their conservation; this work addressed the option of offering activities involving citizen participation with social responsibility and environmental education, with emphasis on children.

Positive scenarios are presented on the relationship between birdwatching tourism and wetlands from sustainable management as strategies for the conservation of wetlands in the city of Bogotá.

The reflective proposal presented in this paper seeks to contribute to the conservation of wetlands, linking society as the main support to achieve change in the current perception of the wetlands of the city of Bogotá, through the relationship between wetlands, birdwatching tourism, society and environmental education.

\section{Acknowledgement}

The authors gratefully acknowledge the EAAB manager Maria Carolina Castillo, JAC of Niza Antigua for allowing us samplings in Wetlands, Jennifer Vega, Camilo Gonzalez for their collaboration in the fieldwork, German Rodriguez by the design of the plans and Dr. Diosey Ramón Lugo for his advice.

\section{References}

1) Fritz K, Cid N, Autrey B. Governance, Legislation and Protection of Intermittent Rivers and Ephemeral StreamsIn . Intermittent Rivers and Ephemeral Streams Ecology and Management. 2017;p. 477-507. Available from: https://doi.org/10.1016/B978-0-12-803835-2.00019-X.

2) Vulnerability Factors to Global Climate Change in the High Andean Colombian Wetlands. 2013. Available from: https://dialnet.unirioja.es/descarga/ articulo/4410560.pdf.

3) Johnson D. Habitat fragmentation effects on birds in Grasslands and wetlands: A critique of our knowledge. Great Plains Research. 2001;11(2):211-231. Available from: https://digitalcommons.unl.edu/cgi/viewcontent.cgi?article=1564\&context=greatplainsresearch.

4) Consequences of habitat loss and fragmentation for wetland amphibian assemblages. 1999. Available from: https://www.researchgate.net/publication/ 225748073_Consequences_of_Habitat_Loss_and_Fragmentation_for_Wetland_Amphibian_Assemblages.

5) and HMSV. Importancia histórica y cultural de los humedales del borde norte de Bogotá (Colombia). Revista UDCA Actualidad \& Divulgación Científica. 2012;15(1):167-180. Available from: https://dx.doi.org/10.31910/rudca.v15.n1.2012.814.

6) Ávila De Navia SL, Estupiñán-Torres SM. Bacteriological quality of the water of the humedal Jaboque. Caldasia. 2006;28(1):67-78. Available from: http://www.scielo.org.co/scielo.php?script=sci_abstract\&pid=S0366-52322006000100007.

7) Pérez-Castillo AG, Rodríguez A. Physicochemical index of water quality for the management of tropical flood lagoons. Revista Biología Tropical. 2008;56(4):1905-1918. Available from: https://www.scielo.sa.cr/pdf/rbt/v56n4/art26v56n4.pdf.

8) Ballén LAC. Aproximación al paisaje de los humedales urbanos de Bogotá dentro de la estructura ecológica principal de la ciudad. Cuadernos de Geografía: Revista Colombiana de Geografía. 2018;27(1):118-130. Available from: https://dx.doi.org/10.15446/rcdg.v27n1.60584.

9) Ocampo-Peñuela N. The phenomenon of migration in birds: a view from the Orinoco. Orinoquía. 2010;14(2):188-200. Available from: http: //www.scielo.org.co/scielo.php?script=sci_abstract\&pid=S0121-37092010000200009.

10) Ochoa D. Good practice guide for birdwatching tourism activity in Colombia. In: Ministry of Commerce, Industry and Tourism. Bogotá. 2017. Available from: https://www.mincit.gov.co/CMSPages/GetFile.aspx?guid=2aaff59c-e5b5-45c7-b0e7-e78304e362f5.

11) Escalona J, Pérez M. Environmental education in the University of Los Andes a study from education student's perspective. Educere. 2006;10(34):483-490.

12) Gutiérrez-Pérez J, Pozo-Llorente T. Theoretical contemporary models and foundation frameworks of environmental education for sustainable development. Revista Iberoamericana de Educación. 2006;41:21-68. Available from: https://rieoei.org/historico/documentos/rie41a01.pdf.

13) Pisanty I, Mazari M, Ezcurra E. The challenge of biodiversity conservation in urban and peri-urban areas. vol. II. Mexico. 2009;p. 719-759.

14) Carrillo JDCG, Lusett MAR. Lógicas de inserción del urbanismo residencial cerrado al sur de Tamaulipas. El periplo sustentable. 2018;33:564-604. Available from: https://dx.doi.org/10.24201/edu.v33i3.1795.

15) Rueda-García L. Guide for the design and operation of interpretive trails. 2004.

16) Castro RD. Volunteerism, altruism and active participation in the preservation of environment. Intervención Psicosocial. 2002;11(3):317-331. Available from: https://www.redalyc.org/pdf/1798/179818139005.pdf.

17) Ochoa EP. Wild birds as bioindicators of environmental pollution and heavy metals. CES Salud Pública. 2014;5:59-69.

18) Villegas M, Álvaro Garitano-Zavala. Bird communities as ecological indictors for environmental monitoring programs in La Paz City. Bolivia Ecología en Bolivia. 2008;43(2):146-153. Available from: http://ecologiaenbolivia.com/documents/Villegas432.pdf.

19) Bayly N, Chaparro-Herrera S. Migratory birds present in the wetlands of Bogotá. In: Birds of the Wetlands of Bogotá, contributions for its conservation. Bogotá. Asociación Bogotana de Ornitología. 2015;p. 39-56.

20) School environmental projects -PRAE in Colombia: nurseries of the new environmental citizenship of a country that is built on the scene of post-conflict and peace. In: and others, editor. Ministry of Environment and Sustainable Development. Bogotá, DC. 2016.

21) Law 115/1994. General Education Law. . Available from: https://www.mineducacion.gov.co/1621/articles-85906_archivo_pdf.pdf. 